\title{
Drug-drug-gene interactions as mediators of adverse drug reactions to diclofenac and statins: a case report and literature review
}

\author{
Nada Božina ${ }^{1,2}$, Lana Ganoci ${ }^{2}$, Livija Simičević ${ }^{2}$, Katarina Gvozdanović ${ }^{3}$, Iva Klarica Domjanović 3 , \\ Margareta Fistrek Prlić ${ }^{4}$, Tena Križ ${ }^{5}$, Ana Borić Bilušić ${ }^{3}$, Mario Laganović ${ }^{1,4}$, and Tamara Božina ${ }^{6}$ \\ ${ }^{1}$ University of Zagreb School of Medicine, Zagreb, Croatia \\ ${ }^{2}$ University Hospital Centre Zagreb, Division of Pharmacogenomics and Therapy Individualization, Department of \\ Laboratory Diagnostics, Zagreb, Croatia \\ ${ }^{3}$ Croatian Agency for Medicinal Products and Medical Devices, Zagreb, Croatia \\ ${ }^{4}$ University Hospital Centre Zagreb, Department of Nephrology, Hypertension, Dialysis, and Transplantation, Zagreb, \\ Croatia \\ ${ }^{5}$ University Hospital Centre “Sestre milosrdnice”, Department of Ophthalmology, Zagreb, Croatia \\ ${ }^{6}$ University of Zagreb School of Medicine, Department of Medical Chemistry, Biochemistry, and Clinical Chemistry, \\ Zagreb, Croatia
}

[Received in April 2021; Similarity Check in April 2021; Accepted in May 2021]

\begin{abstract}
Concomitant treatment with drugs that inhibit drug metabolising enzymes and/or transporters, such as commonly prescribed statins and nonsteroidal anti-inflammatory drugs (NSAIDs), has been associated with prolonged drug exposure and increased risk of adverse drug reactions (ADRs) due to drug-drug interactions. The risk is further increased in patients with chronic diseases/comorbidities who are more susceptible because of their genetic setup or external factors. In that light, we present a case of a 46-year-old woman who had been experiencing acute renal and hepatic injury and myalgia over two years of concomitant treatment with diclofenac, atorvastatin, simvastatin/fenofibrate, and several other drugs, including pantoprazole and furosemide. Our pharmacogenomic findings supported the suspicion that ADRs, most notably the multi-organ toxicity experienced by our patient, may be owed to drug-drug-gene interactions and increased bioavailability of the prescribed drugs due to slower detoxification capacity and decreased hepatic and renal elimination. We also discuss the importance of CYP polymorphisms in the biotransformation of endogenous substrates such as arachidonic acid and their modulating role in pathophysiological processes. Yet even though the risks of ADRs related to the above mentioned drugs are substantially evidenced in literature, pre-emptive pharmacogenetic analysis has not yet found its way into common clinical practice.
\end{abstract}

KEY WORDS: drug interactions; hepatotoxicity; myotoxicity; nephrotoxicity; pharmacogenetics

Inter-individual variability in drug response is a major clinical challenge, as it can result in adverse drug reactions (ADRs) or treatment failure. It is estimated that $80 \%$ of all ADRs depend on the dose and could therefore be prevented $(1,2)$.

The development of ADRs depends on a number of well-known factors, such as age, renal and liver function, and genetic predisposition. In patients receiving concomitant drug treatment, such as those with different syndromes/ comorbidities, especially the elderly, this risk may further increase because of drug-drug interactions (DDIs) $(3,4)$. However, traditional assessment of DDI-related ADR risks needs to take into account individual genetic variations.

Corresponding author: Nada Božina, University Hospital Centre Zagreb, Division of Pharmacogenomics and Therapy Individualization, Department of Laboratory Diagnostics, Kišpatićeva 12, 10000 Zagreb, Croatia E-mail:nbozina@kbc-zagreb.hr
Pharmacogenomics has made much progress in recent times, especially in the field of drug metabolism and transport, and this knowledge should be included in the assessment of clinically relevant ADRs. This particularly refers to drug-gene interactions and drug-drug-gene interactions as important triggers of ADRs (4-7).

Pharmacogenomic research has paid particular attention to phase I [cytochromes P450 (CYPs)] and phase II metabolic enzymes [UDP glucuronosyltransferases (UGTs)], as well as to drug transporters (ABC and SLC superfamilies). CYPs are especially important for variability in drug pharmacokinetics and response as they account for the metabolism of $70-80 \%$ of all drugs (8). Moreover, by mediating the metabolism of endogenous substrates, some CYP enzymes play an important protective and physiological role $(9,10)$ 
Although pharmacogenomic testing can help identify patients at risk of ADRs, its wide application in clinical practice has not yet taken root due to several practical issues, most notably which patients should be tested and how to interpret and include test results in decision making that may, in turn, improve treatment efficacy and safety in patients (11). In addition, little is still known about the usefulness of pharmacogenomic testing in patients undergoing concomitant drug treatment (7).

In this combination of a case report and a review article, we argue that pre-emptive pharmacogenetic analysis, i.e. prior to drug administration, and assessment of drug-druggene interactions could improve personalised approach to drug and dose selection and minimise the risk of ADRs. Yet, even though several laboratories have adopted this approach, it has not taken root in standard clinical practice (12).

\section{CASE PRESENTATION}

On admittance to the hospital emergency department, a 46-year-old Caucasian woman presented with general weakness, difficulty breathing, oliguria and anuria, ascites, and oedema of both lower extremities.

Her medical history was without any serious acute or chronic diseases, but she reported having had regular migraine headaches for the last 10 years, which she treated with diclofenac. The migraines had become severe over the three months preceding admission to the emergency department, and the patient had upped diclofenac doses to $150-200 \mathrm{mg} /$ day. She also reported having had urinary tract infections, for which she had received two 14-day courses of sulphamethoxazole/trimethoprim (400/80 mg bid) therapy.

As no emergency treatment was necessary, the patient was transferred to the nephrology department for further examination. Laboratory tests revealed dyslipidaemia, anaemia, hypokalaemia, hypocalcaemia, and elevated blood urea and creatinine, twice the upper limit of the reference interval (RI) $(9.8 \mathrm{mmol} / \mathrm{L}$ and $176 \mu \mathrm{mol} / \mathrm{L}$, respectively). Urinalysis revealed a high level of proteins $(9 \mathrm{~g} / 24$-hour urine). All this pointed to renal dysfunction, but abdomen ultrasound did not reveal any kidney abnormality (size and cortical echogenicity were normal) and no evidence of urinary tract obstruction.

Patient's history of long-term high-dose diclofenac use raised suspicion of acute kidney injury (AKI) and druginduced minimal change nephrotic syndrome, as both are associated with NSAID use.

One day following admission, a percutaneous kidney biopsy was performed, and histopathological analysis of kidney tissue samples presented complete podocyte effacement, which was accompanied by interstitial inflammation and acute tubular damage. A small segment of sclerosis was also found, as well as myelin figure and zebra corpuscles in one podocyte, raising suspicion of Fabry disease. However, genetic testing found no mutation to support it.

Diclofenac was discontinued, and the patient started receiving intravenous hydration and diuretics. However, renal parameters continued to increase (with creatinine reaching the peak of $559 \mu \mathrm{mol} / \mathrm{L}$ ), and urine output was reduced to $100 \mathrm{~mL}$, despite diuretics. The patient underwent three intermittent courses of haemodialysis and was started on methylprednisolone (at first as $250 \mathrm{mg}$ /day intravenous pulse therapy and then oral doses), which gradually improved her renal function.

All the while she suffered from frequent migraine headaches. A neurologist successfully managed it with a beta-blocker propranolol $(3 \times 20 \mathrm{mg} /$ day $)$ throughout hospitalisation. Twenty days following admission, the patient's creatinine level dropped to $231 \mu \mathrm{mol} / \mathrm{L}$, and daily urine output kept around $2000 \mathrm{~mL}$, but nephrotic proteinuria persisted (11 g/24-hour urine). On day 21 of hospitalisation, she was discharged and prescribed the following oral therapy: furosemide $40 \mathrm{mg}$ /day, prednisone $60 \mathrm{mg} / \mathrm{day}$, pantoprazole $40 \mathrm{mg} /$ day, propranolol $3 \times 20 \mathrm{mg} /$ day for migraines, atorvastatin $20 \mathrm{mg} /$ day for dyslipidaemia, and calcitriol $0.25 \mu \mathrm{g}$ every other day in combination with calcium carbonate $3 \times 1 \mathrm{~g} /$ day (Figure 1 ).

Two weeks following discharge, the patient was readmitted to the emergency department due to a two-day fever (up to $38^{\circ} \mathrm{C}$ ), sweating, and mild chills accompanied by a dry cough and slight pressure along the edge of the sternum. Pleuropneumonia was suspected and confirmed by X-ray along with marked elevation of blood inflammatory markers [C-reactive protein $85.5 \mathrm{mg} / \mathrm{L}(\mathrm{RI}<5.0)$; white blood cells $10.2 \times 10^{9} / \mathrm{L}$ (RI 3.4-9.7); fibrinogen $8 \mathrm{~g} / \mathrm{L}$ (RI 1.8-4.1); and erythrocyte sedimentation rate $115 \mathrm{~mm} / \mathrm{h}$ (RI 4-24 mm/h)]. Markedly elevated blood liver enzymes alkaline phosphatase [ALP 203 U/L (RI 54-119)], alanine aminotransferase [ALT 154 U/L (RI 10-36)], and gammaglutamyl transferase [GGT 205 U/L (RI 9-35)] - indicated liver injury. Total bilirubin was low $(2-3 \mu \mathrm{mol} / \mathrm{L})$, and prothrombin time was normal. Urinalysis pointed to possible urinary tract infection (UTI).

To manage pneumonia and possible UTI due to recent AKI and still not fully recovered renal function the patient was immediately started on IV ceftriaxone $1 \mathrm{~g}$ /day. Further liver tests, abdominal ultrasound, virology, autoimmune tests, and urine culture excluded biliary disease, viral infection, and autoimmune liver disease, but confirmed ascites and UTI with Enterococcus faecalis.

After five days of hospitalisation, chest X-ray follow-up confirmed improvement in the patient's clinical course, but high values of liver enzymes persisted.

On day seven of hospitalisation, GGT and ALP increased significantly (452 U/L and $255 \mathrm{U} / \mathrm{L}$, respectively), while ALT dropped to $107 \mathrm{U} / \mathrm{L}$ but remained well above the RI. Physicians reviewed the patient's laboratory findings from the previous hospitalisation of two weeks earlier and 


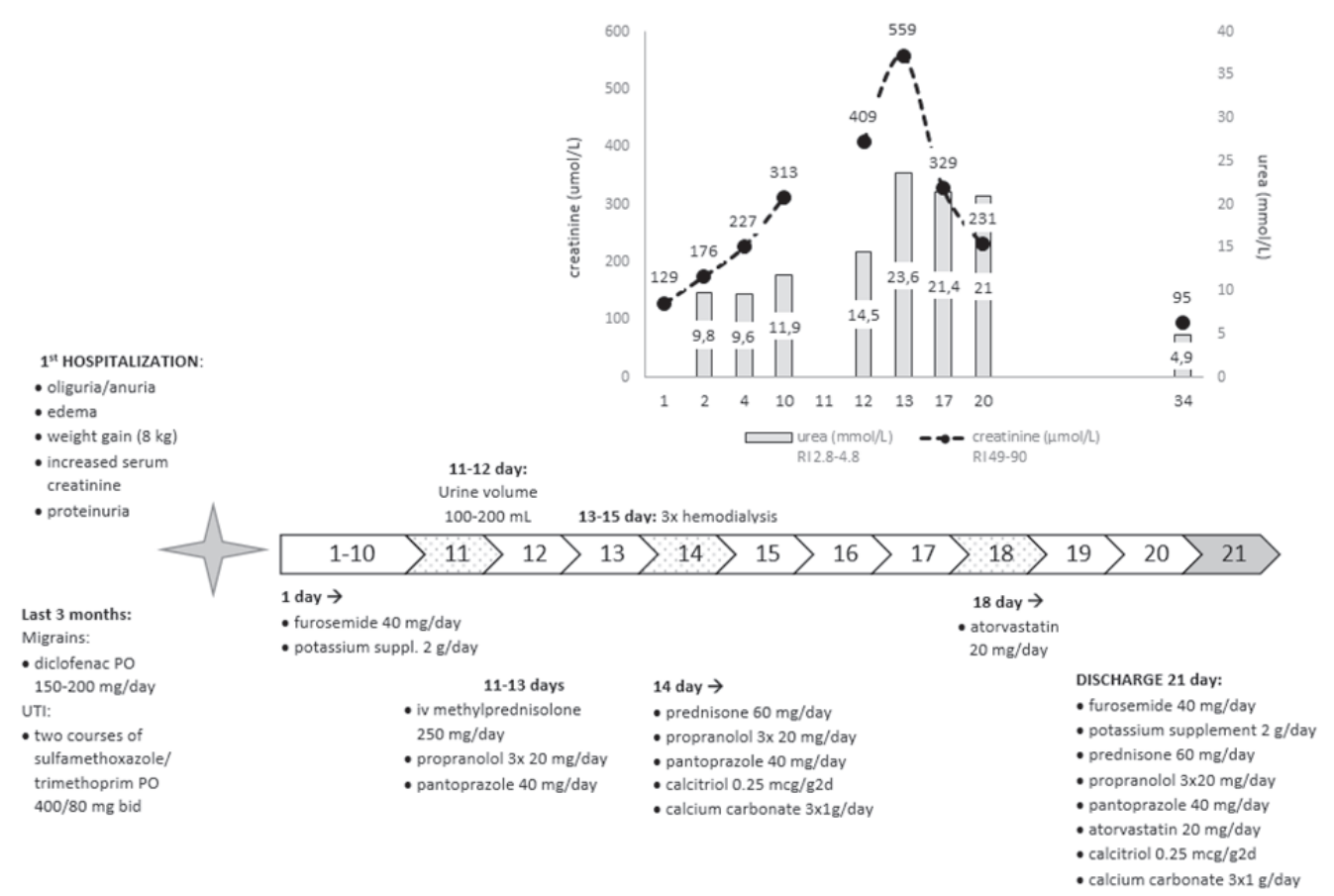

Figure 1 The timeline of the first hospitalisation with all pharmacotherapy and laboratory data

discovered that ALP had slightly increased to $134 \mathrm{U} / \mathrm{L}$ two days after the IV methylprednisolone pulse therapy and that bilirubin levels had been low $(2-3 \mu \mathrm{mol} / \mathrm{L})$. This is what prompted them to check all the patient's medications for potential liver toxicity. Assuming drug-induced liver injury (DILI), they replaced ceftriaxone with oral cefuroxime (1500 mg qid), and prednisone with methylprednisolone, and discontinued atorvastatin treatment.

During the second 15-day hospitalisation, blood urea and creatinine levels were normal, proteinuria decreased noticeably, liver enzyme levels normalised, and ascites withdrew (Figure 2).

On discharge, the following therapy was prescribed: methylprednisolone $40 \mathrm{mg}$ /day, pantoprazole $40 \mathrm{mg} / \mathrm{day}$, furosemide $40 \mathrm{mg} /$ day, propranolol $3 \times 20 \mathrm{mg} /$ day, and calcitriol $0.25 \mu \mathrm{g}$ every other day in combination with calcium carbonate $(3 \times 1 \mathrm{~g} /$ day $)$ and potassium supplement $2 \mathrm{~g} /$ day (potassium citrate/potassium hydrogen carbonate).

The patient's clinical condition was followed up on a regular basis for the next two years (visits every 3-4 months). The patient was in good general health without any acute illnesses, but dyslipidaemia persisted. Two years after the second hospitalisation, the patient started taking a fixed-dose combination of fenofibrate/simvastatin (initially $145 / 20 \mathrm{mg}$, which was later increased to $145 / 40 \mathrm{mg}$ ). At the next follow-up visit three months later, this therapy was discontinued due to elevated creatine kinase (CK) level $[607 \mathrm{U} / \mathrm{L}(\mathrm{RI}<153)]$ and symptoms of myalgia associated with statin-induced myotoxicity. Four weeks after fenofibrate/simvastatin discontinuation, CK dropped to normal, which confirmed ADR in our patient.
Taking all these adverse drug reactions into consideration (drug-induced nephro-, hepato-, and myotoxicity), the patient underwent pharmacogenetic tests for genetic variants of the enzymes and drug transporters relevant for the metabolism and distribution of all medicines she received. The influence of possible drug-drug-gene interactions was also assessed.

\section{Genotyping}

Genomic DNA was extracted from whole blood samples collected in $\mathrm{K}_{3}$-EDTA tubes using the FlexiGene DNA Kit (Qiagen, Hilden, Germany) according to the manufacturer's instructions. Single nucleotide polymorphisms (SNPs) $A B C B 1$ c. $3435 \mathrm{C}>\mathrm{T}$ (rs1045642), $A B C C 2$ c. $-24 \mathrm{C}>\mathrm{T}$ (rs717620), $A B C C 2$ c.1249G $>\mathrm{A}$ (rs2273697), $A B C G 2$ c.421C $>$ A (rs2231142), CYP2C9*2 (rs1799853), CYP2C9*3 (rs1057910), CYP2C19*2 (rs4244285), CYP2C19*17 (rs12248560), CYP2D6*3 (rs35742686), CYP2D6*4 (rs3892097), CYP2D6*6 (rs5030655), CYP2D6*41 (rs28371725), CYP3A4*22 (rs35599367), CYP3A5*3 (rs776746), SLCO1B1 c.521T >C (rs4149056), UGT1A4*2 (rs6755571), UGT1A4*3 (rs2011425), UGT1A9 $-2152 \mathrm{C}>\mathrm{T}(\mathrm{rs} 17868320),-275 \mathrm{~T}>\mathrm{A}(\mathrm{rs} 6714486)$, and UGT2B7 -161C > T (rs7668258), were genotyped for with the TaqMan ${ }^{\circledR}$ SNP genotyping assays on a 7500 Real-Time PCR System (Applied Biosystems, Carlsbad, CA, USA) according to the manufacturer's instructions. UGT1A1*28 was genotyped for with the LightSNiP genotyping assay (TIB Molbiol GmbH, Berlin, Germany) and $A B C B 1$ c. $2677 \mathrm{G}>\mathrm{T} / \mathrm{A}$ (rs2032582) with real-time PCR genotyping on a LightCycler ${ }^{\circledR}$ 2.0. Instrument (Roche Diagnostics, 


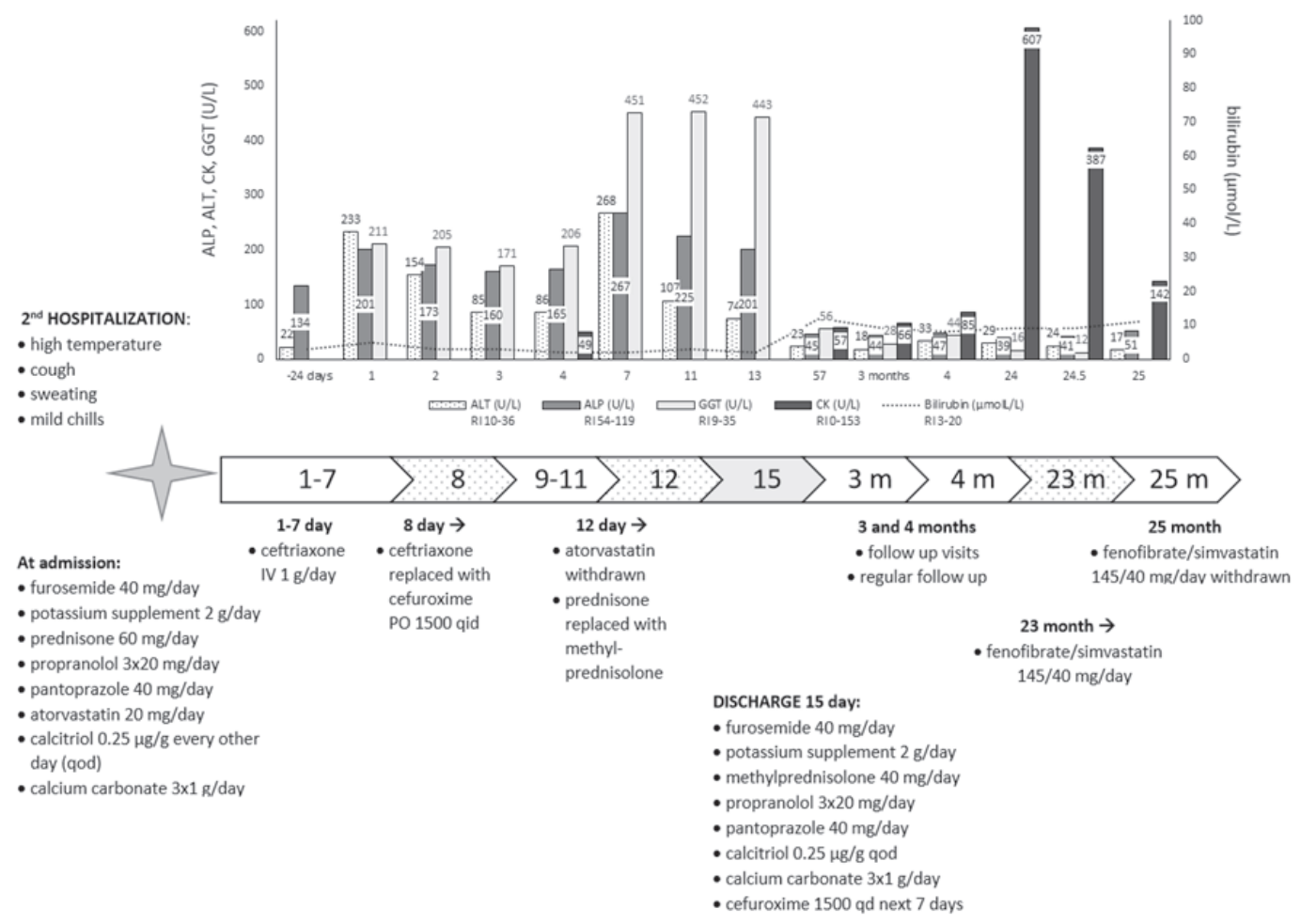

Figure 2 The timeline of the second hospitalisation with all pharmacotherapy and laboratory data

Mannheim, Germany) as described elsewhere (13). CYP2D6*5 whole gene deletion and CYP2D6 gene duplications were genotyped for with long-range PCR analysis on a Gene Amp PCR System 9700 (Applied Biosystems) as reported elsewhere $(14,15)$. All genotyping took place in a pharmacogenetic testing laboratory that regularly participates in external quality assessment schemes (RfB and EMQN).

Our findings are presented in Table 1. Based on these findings, relevant published research, and the guidelines and recommendations of pharmacogenetics consortia, including The Clinical Pharmacogenetics Implementation Consortium (CPIC) (16) and the Dutch Pharmacogenetics Working Group (DPWG) (17) for simvastatin, atorvastatin, NSAIDs, and pantoprazole, our patient was advised which drugs not to take and was prescribed alternative therapy with a lower simvastatin and atorvastatin doses in accordance with current guidelines. Creatine kinase (CK) was monitored routinely to introduce a replacement statin (pravastatin or rosuvastatin) should CK levels rise. Further treatment excluded the combination of simvastatin/ atorvastatin and fenofibrate. Furthermore, the patient was advised not to take CYP2C9 substrate drugs over longer periods of time or to use the lowest effective doses when necessary, but under monitoring for signs of toxicity. This advice particularly referred to coumarin anticoagulants, some NSAIDs (celecoxib, flurbiprofen, ibuprofen, lornoxicam), and meloxicam. The recommendation for meloxicam was to start with half the lowest recommended starting dose and titrate it carefully up to clinical effect or up to half the maximum recommended dose. Monitoring for signs of toxicity was advised for short-term application, while for longer-term therapy an alternative drug, not a CYP2C9 substrate, was recommended. Treatment with propranolol was also to be monitored for signs of toxicity, and other CYP2D6 substrate drugs to be administered with caution.

\section{DISCUSSION AND REVIEW OF DRUG- DRUG-GENE INTERACTIONS}

This brief review is focused on diclofenac and statins as the ones associated with ADRs found in our patient. What suggests that the issue may be widespread is the fact that these two drugs are among top prescriptions in Croatia (18) and many other countries.

As a NSAID, diclofenac is indicated for pain relief and inflammation in a wide range of conditions. Following oral uptake, it is mainly eliminated via hepatic biotransformation, while less than $1 \%$ is excreted unchanged through urine (Figure 3). In the liver it is mainly metabolised through oxidation and conjugation to glucuronic acid (19). Oxidation to the major metabolite 4'-hydroxydiclofenac is mediated by CYP2C9, while oxidation to the minor metabolite 5'-hydroxydiclofenac is mediated by CYP2C8, CYP3A4, and CYP2C19 (20). Diclofenac acyl glucuronide as the product of conjugation, in turn, is mainly mediated 
Table 1 Pharmacogenetic profile of our patient and related pharmacotherapy

\begin{tabular}{|c|c|c|c|c|}
\hline Gene-allele & Genotype & Phenotype & Drug-substrate & Drug-inhibitor \\
\hline$C Y P 2 C 9 * 2, * 3$ & $* 1 / * 3$ & intermediate metaboliser - IM & $\begin{array}{l}\text { diclofenac } \\
\text { sulphamethoxazole } \\
\text { trimethoprim }\end{array}$ & $\begin{array}{l}\text { atorvastatin } \\
\text { fenofibrate } \\
\text { simvastatin } \\
\text { sulphamethoxazole }\end{array}$ \\
\hline CYP2C19*2, *17 & $* 1 / * 1$ & normal metaboliser - NM & $\begin{array}{l}\text { diclofenac } \\
\text { pantoprazole } \\
\text { propranolol }\end{array}$ & $\begin{array}{l}\text { pantoprazole } \\
\text { atorvastatin }\end{array}$ \\
\hline $\begin{array}{l}\text { CYP } 2 D 6 * 3, * 4, * 5, * 6 \\
* 41, x N\end{array}$ & $* 1 / * 4$ & $\underline{\text { intermediate metaboliser - IM }}$ & propranolol & $\begin{array}{l}\text { atorvastatin } \\
\text { propranolol }\end{array}$ \\
\hline CYP $3 A 4 * 22$ & $* 1 / * 1$ & normal metaboliser - NM & $\begin{array}{l}\text { atorvastatin } \\
\text { diclofenac } \\
\text { pantoprazole } \\
\text { propranolol } \\
\text { prednisone } \\
\text { simvastatin }\end{array}$ & $\begin{array}{l}\text { diclofenac } \\
\text { pantoprazole }\end{array}$ \\
\hline CYP $3 A 5 * 3$ & $* 3 / * 3$ & non-expresser & $\begin{array}{l}\text { atorvastatin } \\
\text { propranolol } \\
\text { simvastatin }\end{array}$ & \\
\hline$U G T 1 A 1 * 28$ & $* 1 / * 28$ & $\begin{array}{l}\text { intermediate enzyme } \\
\text { activity }\end{array}$ & $\begin{array}{l}\text { atorvastatin } \\
\text { furosemide } \\
\text { simvastatin }\end{array}$ & $\begin{array}{l}\text { atorvastatin } \\
\text { pantoprazole }\end{array}$ \\
\hline$U G T 1 A 4 * 2(70 C>A)$ & $* 1 / * 1$ & normal enzyme activity & atorvastatin & \\
\hline$U G T 1 A 4 * 3(142 T>G)$ & $* 1 / * 3$ & $\begin{array}{l}\text { intermediate enzyme } \\
\underline{\text { activity }}\end{array}$ & atorvastatin & fenofibrate \\
\hline UGT1A9 $(-2152 C>T)$ & $\mathrm{C} / \mathrm{C}$ & normal enzyme activity & $\begin{array}{l}\text { fenofibrate } \\
\text { atorvastatin }\end{array}$ & fenofibrate \\
\hline$U G T 1 A 9(-275 T>A)$ & $\mathrm{T} / \mathrm{T}$ & normal enzyme activity & $\begin{array}{l}\text { fenofibrate } \\
\text { atorvastatin }\end{array}$ & fenofibrate \\
\hline$U G T 2 B 7-161 C>T$ & $\mathbf{T} / \mathbf{T}$ & $\begin{array}{l}\text { substrate depending low/ } \\
\text { high enzyme activity }\end{array}$ & $\begin{array}{l}\text { atorvastatin } \\
\text { diclofenac } \\
\text { propranolol } \\
\text { simvastatin }\end{array}$ & fenofibrate \\
\hline $\begin{array}{l}A B C B 1(M D R 1) \\
2677 G>T / A \\
A B C B 1(M D R 1) \\
3435 C>T\end{array}$ & $\begin{array}{l}\mathrm{G} / \mathrm{G} \\
\mathbf{T} / \mathbf{T}\end{array}$ & $\begin{array}{l}\text { decreased transporter } \\
\underline{\text { function }}\end{array}$ & $\begin{array}{l}\text { atorvastatin } \\
\text { pantoprazole } \\
\text { prednisone } \\
\text { propranolol } \\
\text { simvastatin }\end{array}$ & $\begin{array}{l}\text { atorvastatin } \\
\text { ceftriaxone } \\
\text { furosemide } \\
\text { pantoprazole }\end{array}$ \\
\hline $\begin{array}{l}A B C C 2(M R P 2)-24 C>T \\
A B C C 2(M R P 2) \\
1249 G>A\end{array}$ & $\begin{array}{l}\mathrm{C} / \mathrm{C} \\
\mathrm{G} / \mathrm{G}\end{array}$ & normal transporter function & $\begin{array}{l}\text { atorvastatin } \\
\text { ceftriaxone } \\
\text { diclofenac } \\
\text { simvastatin }\end{array}$ & furosemide \\
\hline$A B C G 2421 C>A$ & $\mathrm{C} / \mathrm{A}$ & $\begin{array}{l}\text { decreased transporter } \\
\underline{\text { function }}\end{array}$ & $\begin{array}{l}\text { atorvastatin } \\
\text { ceftriaxone } \\
\text { diclofenac } \\
\text { fenofibrate } \\
\text { pantoprazole }\end{array}$ & $\begin{array}{l}\text { furosemide } \\
\text { pantoprazole }\end{array}$ \\
\hline$S L C O 1 B 1 * 5$ & $* 1 \mathrm{~A} / * 5$ & $\begin{array}{l}\text { decreased transporter } \\
\underline{\text { function }}\end{array}$ & $\begin{array}{l}\text { atorvastatin } \\
\text { diclofenac } \\
\text { simvastatin }\end{array}$ & $\begin{array}{l}\text { atorvastatin } \\
\text { diclofenac } \\
\text { fenofibrate }\end{array}$ \\
\hline
\end{tabular}


by UGT2B7 (21). Approximately $65 \%$ of diclofenac is excreted as oxidative metabolites via the kidneys, while the remaining $35 \%$ is excreted as glucuronide metabolites in faeces via bile (22).

In vivo studies have shown that diclofenac and its glucuronide metabolites are substrates for efflux transporters: multidrug resistance protein 2 (MRP2/ABCC2), 3 (MRP3/ $\mathrm{ABCC} 3)$, and the breast cancer resistance protein (BCRP/ ABCG2) (23-25).

Statins are the first-line treatment for hypercholesterolemia in both primary and secondary prevention of cardiovascular disease (26). Simvastatin is a prodrug, administered as inactive lactone and then converted to open hydroxy acid form (27). Atorvastatin is orally administered in active acid form (28). Both undergo extensive first-pass metabolism in the intestine and liver (Figure 4), mediated primarily by CYP3A4 with a minor contribution of CYP2C9 and CYP3A5 (29-32). The main enzymes involved in statin glucuronidation are UGTs (1A1, 1A3, 2B7) (27, 33-37).

Of the drug transporters, P-glycoprotein (encoded by $M D R 1 / A B C B 1$ ) and BCRP/ABCG2 (encoded by $A B C G 2$ ) mediate intestinal and biliary efflux of statins $(38,39)$, while OATP1B1 has a central role in hepatic uptake (40-42).

As the majority of CYPs and UGTs are polymorphic, their gene polymorphisms can affect the outcome of drug therapy (10). Transporters too have an important role in drug fate within the human body. Their interplay, along with pharmacogenetic variability, can change drug metabolism and reuptake of substances, prolonging drug bioavailability and increasing the risk of ADRs $(43,44)$

There is considerable interindividual variation in susceptibility to the most common ADRs to both of these drugs, yet pre-emptive genetic testing has not yet taken root in regular clinical practice. There are several reasons for this, including insufficient training of healthcare professionals about this issue, insufficient strong evidence linking pharmacogenetic data with clinical outcomes, and a lack of cost-benefit analysis. Pharmacogenetic tests are mostly done retrospectively, as was our case, to identify and explain unexpected ADRs or therapeutic failure in a patient. In our patient the tests revealed the presence of several loss-of-function gene variants for metabolic enzymes and drug transporters (CYP2C9, UGTs, ABCs, and SLCO1B1), which pointed to drug-drug-gene interactions contributing to prolonged bioavailability of applied drugs as additional relevant factor for the observed drug-induced ADRs (nephrotoxicity, hepatotoxicity, statinassociated muscle symptoms, and elevated CK).

\section{Diclofenac nephrotoxicity}

There are several possible mechanisms of genetic influence on diclofenac nephrotoxicity. Diclofenac inhibits prostaglandin biosynthesis from arachidonic acid in the kidney by inhibiting cyclooxygenase enzymes (45). The vasodilating effect of prostaglandins increases renal blood flow and glomerular filtration rate. Their inhibition, in turn, reduces renal blood flow, which may lead to peripheral oedema, increased pressure, body weight, and acute renal failure (46). All these symptoms have been observed in our patient.

NSAIDs are known to cause kidney failure even at therapeutic doses, as they interfere with the vasodilation response of renal prostaglandins to vasoconstrictor hormones released by the body (47). However, this effect is often overlooked, because the symptoms are usually moderate and transitory or even absent, like with the absence of anuria (48). ADRs to diclofenac can be potentiated further by pharmacogenetic variants affecting absorption, distribution, metabolism, and excretion (ADME), and our patient had several that could have contributed to weaker diclofenac metabolism $(C Y P 2 C 9 * 3$, $U G T 2 B 7-161 T T$, and $U G T 1 A 1 * 28$ ) and transport (ABCB1 $3435 T T$ and $A B C G 2$ 421CA).

In vitro studies have shown that $C Y P 2 C 9 * 3$ and other CYP 2 C9 alleles $* 5, * 8, * 13$, and $* 35$ significantly decrease diclofenac metabolism (49-51) but not CYP2C9*2 (51). Conflicting results have been obtained in clinical studies. While some indicate that $C Y P 2 C 9 * 3$ is associated with decreased diclofenac metabolism (higher diclofenac to 4-'hydroxy-diclofenac metabolic ratio in urine) (52), other more convincing data show no association between CYP $2 C 9 * 3$ polymorphism and increased oral diclofenac plasma concentration or lower clearance (53). The CPIC guideline (54) states that the pharmacokinetics of diclofenac is not affected by the CYP2C 9 genotype and there is not enough evidence to provide recommendation for clinical practice.

It is important that, besides diclofenac metabolism, the CYP2C9*3 variant may have had an additional effect on the development of nephrotoxicity. One of the physiological roles of some CYP enzymes is to mediate metabolism of arachidonic acid (AA) (55). Since the knowledge about this third AA metabolism pathway emerged (in addition to lipoxygenase and cyclooxygenase), subsequent research has revealed that its products, epoxyeicosatrienoic acids (EETs) (56) and 20-hydroxyeicosatetraenoic acid (20HETE), have essential roles in regulating renal tubular and vascular function, such as lowering pressure and protecting against renal and vascular injury by reducing inflammation, oxidative stress, and endothelial dysfunction $(57,58)$.

Furthermore, some studies suggest that CYP variants mediating weaker AA metabolism can contribute to kidney damage (59) and that carriers of loss-of-function alleles $C Y P 2 C 9 * 2$ and $C Y P 2 C 9 * 3$ have reduced EET production (60). Furthermore, loss-of-function $C Y P 2 C 8^{*} 3, C Y P 2 C 9^{*} 2$, $C Y P 2 C 9 * 3$, and $C Y P 2 J 2 * 7$ variants have been associated with endothelial dysfunction, myocardial infarction, and stroke (61-64).

As our patient is the carrier of the loss-of-function allele $C Y P 2 C 9 * 3$, we can assume that reduced EET production 


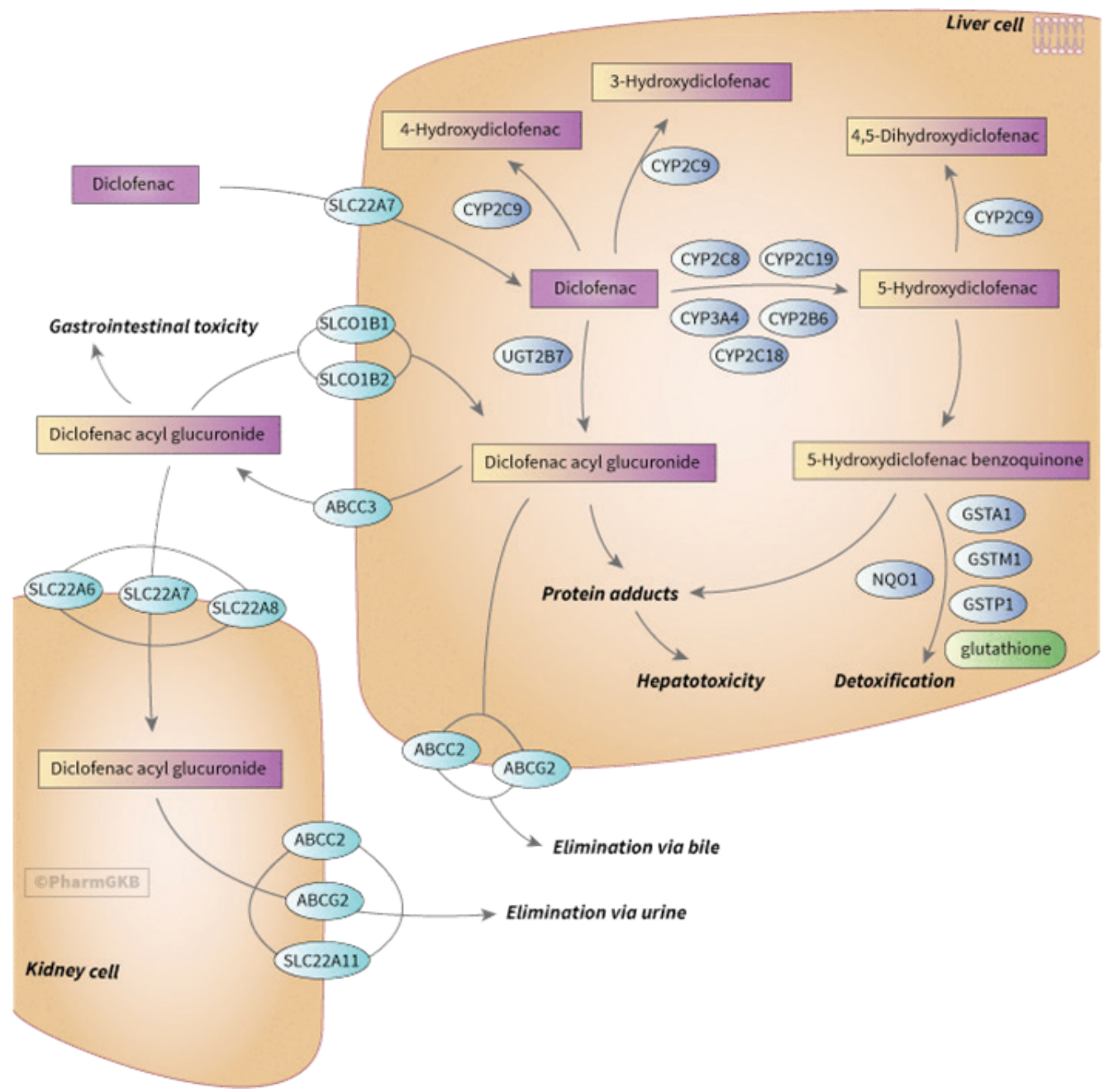

Figure 3 Diclofenac transport and metabolism (adopted from PharmGKB pathway images at https://www.pharmgkb.org/pathway/ PA166163705 under the Creative Commons BY-SA 4.0 license)

increased her susceptibility to the nephrotoxic effect of diclofenac.

Increased levels of 20 -HETE pose the risk of cardiovascular diseases (65) and glomerular injury (57). 20-HETE elimination in humans mainly follows the glucuronidation pathway by UGTs and can vary 10 times between individuals (66). 20-HETE glucuronidation extensively correlates with the UGT2B7 and UGT1A9 protein expression (65) and is under considerable control of their genetic polymorphisms (UGT2B7 802C $>\mathrm{T}$, $U G T 1 A 9-118 \mathrm{~T} 9>\mathrm{T} 10$, and $U G T 1 A 91399 \mathrm{C}>\mathrm{T})$ in the liver. The UGT2B7 802TT genotype significantly decreases 20 HETE glucuronidation (65). As the UGT2B7 802C $>\mathrm{T}$ polymorphism is in complete linkage disequilibrium with the $-U G T 2 B 7-161 C>T$ polymorphism $(67,68)$ we can assume that the UGT2B7-161TT genotype in our patient was responsible for slower glucuronidation and 20-HETE elimination and may have contributed to kidney failure. In addition to the genetic $U G T 2 B 7802 \mathrm{C}>\mathrm{T}(* 2)$ variant, recent data point to a significant role of NSAID, above all diclofenac, in the inhibition of 20-HETE glucuronidation, which may have further potentiated nephrotoxicity (69).

\section{Drug-induced hepatotoxicity}

As the $C Y P 2 C 9 * 3$ variant can lower diclofenac oxidation to the major metabolite, 4'-hydroxydiclofenac, this could lead to increased production of the minor metabolite 5'-hydroxydiclofenac via CYP2C8, CYP3A4, and CYP2C19 and the formation of hepatotoxic benzoquinones such as diclofenac-2, 5-quinone imines (70). Along with diclofenac acyl glucuronide, these proteinreactive diclofenac-2,5-quinone imines have been suggested to play an important role in diclofenac hepatotoxicity (70).

UGT2B7 has the main role in diclofenac glucuronidation. UGT2B7 polymorphisms were shown to have substratedependent effects on catalytic activity, and its variants can be associated with no effect $(71,72)$, decreased $(73,74)$, or even increased enzyme activity $(75,76)$. Some studies indicate that $U G T 2 B 7^{*} 2(802 \mathrm{~T} /-161 \mathrm{~T})$ is more frequent in patients with diclofenac-induced hepatotoxicity $(68,77)$, which is associated with reduced diclofenac acyl glucuronidation and increased bioactivation to quinonimines, resulting in increased risk of diclofenac-induced liver damage (70). 


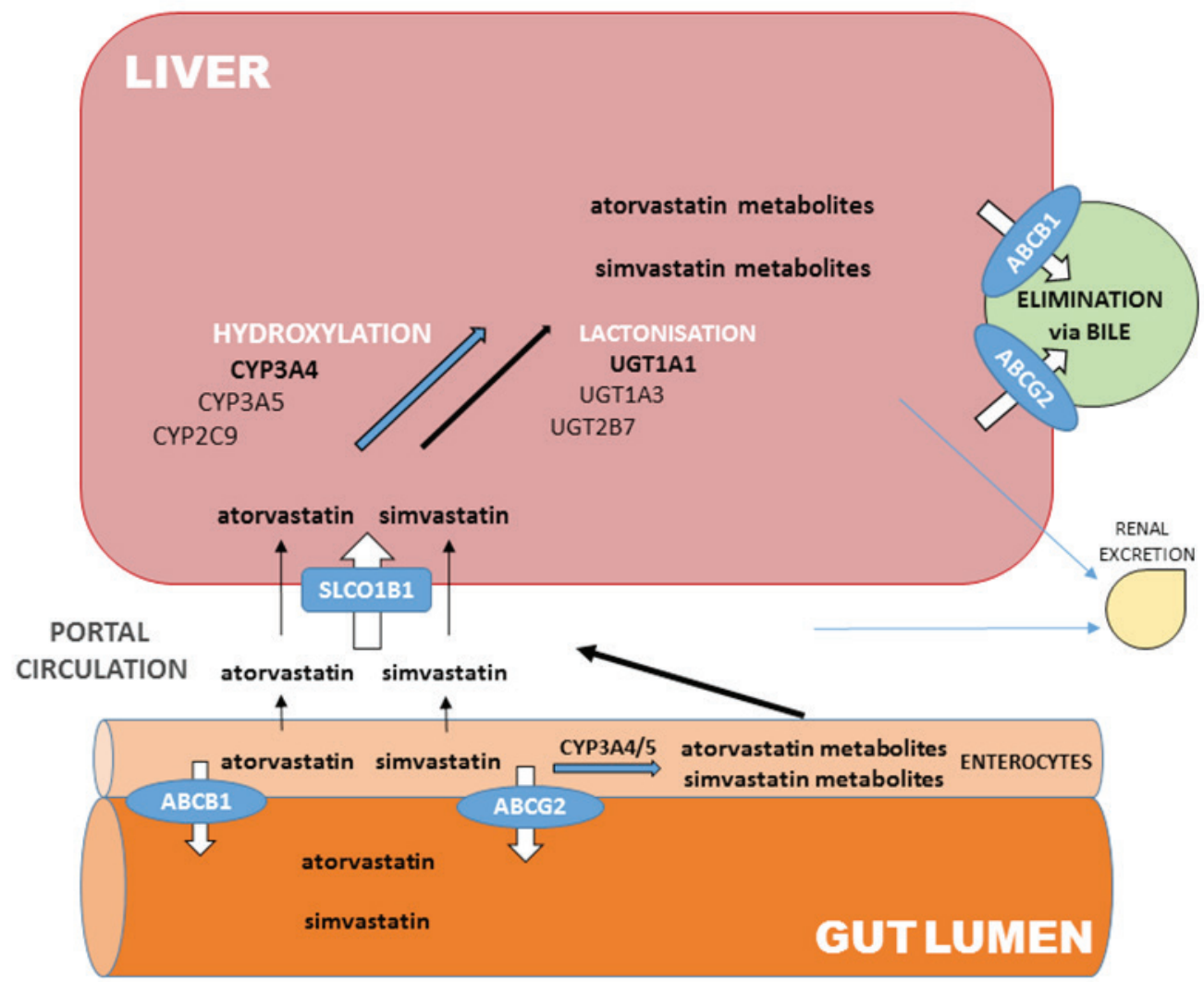

Figure 4 Major statins transport and metabolism pathways (own illustration)

The bioavailability of diclofenac, furthermore, depends on the function of ABCC2 (MRP2) and ABCG2 (BCRP) transporters, which are involved in its absorption, distribution, and excretion $(78,79)$. In our patient the $A B C G 2$ gene variant may have therefore decreased the function of this transporter and contributed to drug accumulation and nephrotoxicity due to delayed excretion. We believe that due to the above described mechanisms of diclofenac metabolism, our patient's liver function may have already been sensitised and more prone to hepatotoxicity induced by other drugs, which developed two weeks later. This conclusion stems from the fact that the signs of hepatotoxicity developed in our patient two weeks after hospital discharge, during which time she was receiving atorvastatin, propranolol, furosemide, pantoprazole, prednisone, and calcitriol. This is a rather short time for atorvastatin to induce liver injury, were it not for previous sensitisation. Admittedly, liver injury could also have been exacerbated by ceftriaxone prescribed in the hospital, which points to other factors, including polypharmacy, as additional risk of DILI.

Even so, atorvastatin-induced liver injury (AILI) has amply been evidenced following atorvastatin treatment $(81$, 82). Post-marketing surveillance revealed that $1.5 \%$ of patients who received atorvastatin treatment suffered from liver injury.

Possible hepatotoxicity predispositions in our patient included prolonged exposure to diclofenac, atorvastatin- related hepatotoxicity, and pharmacogenetics of $A B C B 1$ and $A B C G 2$. Our patient is a carrier of the $A B C B 13435 T T$ and $2677 G G$ genotype. The effects of ABCB1 (MDR1) transporter on the pharmacokinetics of statins have been reported in several studies $(38,83,84)$, and variantweakened transport activity could lead to lower biliary clearance and hepatic accumulation of atorvastatin. $A B C B 1$ polymorphisms rs $1128503(1236 \mathrm{C}>\mathrm{T}), \mathrm{rs} 2032582$ $(2677 \mathrm{G}>\mathrm{T} / \mathrm{A})$, and rs $1045642(3435 \mathrm{C}>\mathrm{T})$ have been shown to markedly affect atorvastatin area under the plasma concentration-time curve (AUC) (38). However, a recently published study did not establish an association between $A B C B 1$ polymorphisms and the bioavailability of atorvastatin (85).

One study (86) pointed to the association between AILI and the $A B C B 12677 \mathrm{G}>\mathrm{T} / \mathrm{A}$ variant (rs2032582) in a Japanese population. Carriers of the $A B C B 12677 \mathrm{G}$ variant (like our patient) were more vulnerable to AILI, which was also confirmed by a cytotoxicity test in vitro in the same study. Since no differences were observed in atorvastatin bioavailability between Asian and Caucasian populations (87), the increased risk of AILI associated with the $A B C B 1$ rs2032582 allele might therefore also apply for the Caucasian population and our patient. Atorvastatin accumulation in the liver of our patient might have been exacerbated by the interaction with concomitantly administered pantoprazole, a known substrate and inhibitor of MDR1/ABCB1 (88). 
Polymorphic ABCG2 is an efflux transporter with significant function in numerous tissues, as it modulates the bioavailability of many drugs, including statins (89). Our patient is a carrier of the $A B C G 2421 \mathrm{C}>\mathrm{A}$ variant, associated with reduced transporter activity, which suggests that she could have been exposed to higher systemic and hepatic atorvastatin levels $(39,90)$. The Keskitalo group (39) found that carriers of the c.421AA genotype had a $72 \%$ larger mean atorvastatin AUC than those with the c.421CC genotype. Another study (91) in a Japanese population revealed that patients carrying the rs $2622604 A B C G 2$ allele variant had a $55 \%$ increase in oral atorvastatin bioavailability vs non-carriers.

In line with these increased bioavailability findings, our previous research (92) showed that patients with $A B C G 2$ $421 C A$ or $A A$ genotypes had 2.9 times higher odds of developing atorvastatin dose-dependent ADRs. Even after adjustments for clinical and other genetic risk factors, ABCG2 remained statistically significant for ADRs. The relevance of the ABCG drug transporter has also been recognised by regulatory authorities $(93,94)$, which recommend that the development of new medicinal products should take into account whether they are substrates or inhibitors of ABCG2. The incidence of $A B C G 2$ gene variants varies greatly among populations and races. It is significantly higher in the Asian (30\%) than Caucasian $(10-15 \%)$ and black $(2 \%)$ populations $(39,95)$.

Although the views on the role of UGTs as predictors of atorvastatin pharmacokinetics and toxicity still diverge $(35,96,97)$, we believe that the UGT1A1, UGT1A4, and $U G T 2 B 7$ gene variants in our patient could have had some influence on prolonged atorvastatin systemic and hepatic exposure and susceptibility to ADRs, including liver damage.

Some authors suggest that these inconsistencies considering $U G T$ gene variants are due to extensive linkage disequilibrium in the $U G T 1 A$ locus $(29,35)$.

\section{Statin-associated muscle symptoms}

Myopathy is one of the most serious ADRs to statins $(98,99)$. Pharmacogenetic testing has shown that our patient is a heterozygous carrier of the decreased function allele SLCO1B1 521T $>\mathrm{C}$, which is associated with elevated systemic exposure to several statins (100) and an increased risk of myotoxicity. However, short-term (two-week) administration of atorvastatin did not produce this effect in our patient. Instead, she developed signs of myotoxicity, i.e. myalgia and elevated CK only when simvastatin was administered in combination with fenofibrate and then she had to discontinue simvastatin.

The SLCO1B1*5 (c.521T>C, p.V174A, rs4149056) variant has been associated with a $221 \%$ higher systemic exposure to simvastatin acid in carriers of the $521 C C$ genotypes than in the wild-type carriers (521TT). Although to a lesser extent, the relevance of this polymorphism was confirmed for other statins (85) as well, except for fluvastatin (100). Atorvastatin AUC increased $145 \%$ in $521 C C$ carriers (100). The prevalence of rs4149056 is estimated to be $1 \%, 12 \%$, and $16 \%$ in Africans, East Asians, and Europeans, respectively (101). We therefore assume that the SLCO1B1 polymorphism in our patient slowed down hepatic uptake of simvastatin and increased its bioavailability in systemic circulation, making her more prone to myotoxicity and interactions with other drugs, including fenofibrate.

Fibrates can increase the risk of statin ADRs due to pharmacodynamic and pharmacokinetic interactions (102). Although this ADR risk for simvastatin and fenofibrate combination is low in general population, it increases in patients with a pharmacogenetic predisposition, like in carriers of the ADME gene variants that prolong drug exposure. We believe this to have been the case with our patient as a carrier of several polymorphisms $\left(U G T 1^{*} 28\right.$, $U G T 2 B 7$-161T, ABCB1 3435T, ABCG2 421A and $S L C O 1 B 1521 C$ ), as she developed signs of myotoxicity and elevated $\mathrm{CK}$ after taking the simvastatin/fenofibrate combination.

In vitro, fenofibric acid is a mild-to-moderate inhibitor of CYP2C9, weak inhibitor of CYP2C8, CYP2C19, and CYP2A6 (103,104), and moderate inhibitor of MDR1 and to a minor degree of OATP1B1 (105). In vivo, it inhibits hepatic MDR1 (106). Most of active fenofibric acid undergoes glucuronidation by the UGT isoforms (1A9 and 2B7), forming glucuronides which are excreted in the urine and bile (26).

Since simvastatin also uses UGT enzymes for its biotransformation (Figure 2), interactions through UGTs can be expected, especially if the enzyme activity is reduced due to genetic predisposition.

\section{Drug-drug, drug-gene, and drug-drug-gene interactions}

The concomitant use of medicinal products should consider all three types of interactions (drug-drug, druggene, and drug-drug-gene) as relevant factors in ADRs. In our patient, diclofenac with sulphamethoxazole/ trimethoprim resulted in nephrotoxicity, atorvastatin with furosemide, pantoprazole, and ceftriaxone resulted in hepatotoxicity, while the simvastatin/fenofibrate fixed-dose combination resulted in myotoxicity. Sulphamethoxazole and trimethoprim are both substrates of CYP2C9 and can inhibit CYP2C9 and CYP2C8 activities, respectively (107), which in the case of our patient as a carrier of the loss-offunction $C Y P 2 C 9 * 3$ variant could be of even greater significance.

Proton pump inhibitors (PPIs) and loop diuretics have recently been associated with modest increases in the levels of atorvastatin and its metabolites (14\% and $38 \%$, respectively) (108). PPIs inhibit the CYP2C9, 2C19, 2D6, and 3A4 enzymes, which can result in interactions with other drugs which are the substrates of these enzymes (109). 
Furthermore, PPIs have been reported to interact with drug efflux transporters $\mathrm{ABCB} 1$ and $\mathrm{ABCG} 2$ both as inhibitors and substrates (110-112).

Since ceftriaxone, which was replaced in our patient over the risk of increased hepatotoxicity (113), is a substrate of ABCC2 and ABCG2 transporters, drug-drug interactions at this level should also be taken into consideration.

As for furosemide, it has been identified as a substrate for OAT1, OAT3, BCRP/ABCG2, OATP1B1, and OATP1B3 and a potent inhibitor of BCRP in vitro $(114,115)$. The $A B C G 2$ rs2231142 (141K) variant, however, may attenuate BCRP-mediated loop diuretic-atorvastatin interaction, yet Turner et al. (108) did not establish any interaction between atorvastatin and furosemide in relation to the $A B C G 2 \mathrm{rs} 2231142(421 C>\mathrm{A}, \mathrm{Q} 141 \mathrm{~K})$ variant, most probably because their study included too few carriers. They concluded that the magnitude of the identified PPI and loop diuretic interactions at the population level were modest and of questionable clinical relevance. However, they also added that these newly discovered drug interactions could contribute to the risk of ADRs in specific patients - such as ours - who already have other risk factors for prolonged drug exposure, including comorbidities and polypharmacy. This consideration was confirmed by Klarica Domjanović et al. (116), who showed that the $A B C G 2421 \mathrm{C}>\mathrm{A}$ polymorphism significantly modulated drug-drug interactions between valproate and lamotrigine.

\section{CONCLUSIONS}

In our patient, ADRs were the consequence of interactions between drugs and ADME-affecting gene variants encoding for metabolic enzymes (CYPs and UGTs) and drug transporters ABCB1, ABCG2, and SLCO1B1. ADME pharmacogenetic variants can significantly modulate/increase the range of drug-drug interactions, prolonging their bioavailability and leading to ADRs as a result. In addition, variations in CYP and UGT enzyme function may reflect on the biotransformation of endogenous substrates such as arachidonic acid. Through inflammation, oxidative stress, and endothelial dysfunction, this may add to the risk of organ damage.

A number of ADRs could have been prevented by pharmacogenetic testing in advance of treatment with diclofenac, atorvastatin, and simvastatin/fenofibrate. This testing could also have provided information about possible drug-drug-gene interactions in concomitant therapy, especially with sulphamethoxazole/trimethoprim, pantoprazole, and furosemide. This is why we believe that drug-drug-gene interactions deserve further comprehensive studies and that pharmacogenetic testing should find its rightful place in managing patients with polypharmacy.

\section{Acknowledgements}

We would like to thank our patient for consenting to the publication of this case report.

\section{Conflicts of interest}

None to declare.

\section{REFERENCES}

1. Routledge PA, O’Mahony MS, Woodhouse KW. Adverse drug reactions in elderly patients. Br J Clin Pharmacol 2004;57:121-6. doi: 10.1046/j.1365-2125.2003.01875.x

2. Alhawassi TM, Krass I, Bajorek BV, Pont LG. A systematic review of the prevalence and risk factors for adverse drug reactions in the elderly in the acute care setting. Clin Interv Aging 2014;9:2079-86. doi: 10.2147/CIA.S71178

3. US Food and Drug Administration. Preventable Adverse Drug Reactions: A Focus on Drug Interactions 2018 [displayed 30 December 2020]. Available at https://www. fda.gov/drugs/drug-interactions-labeling/preventableadverse-drug-reactions-focus-drug-interactions

4. Malki MA, Pearson ER. Drug-drug-gene interactions and adverse drug reactions. Pharmacogenomics J 2020;20:35566. doi: 10.1038/s41397-019-0122-0

5. Verbeurgt P, Mamiya T, Oesterheld J. How common are drug and gene interactions? Prevalence in a sample of 1143 patients with CYP2C9, CYP2C19 and CYP2D6 genotyping. Pharmacogenomics 2014;15:655-65. doi: 10.2217/pgs.14.6

6. Bahar MA, Setiawan D, Hak E, Wilffert B. Pharmacogenetics of drug-drug interaction and drug-drug-gene interaction: a systematic review on CYP2C9, CYP2C19 and CYP2D6. Pharmacogenomics 2017;18:701-39. doi: 10.2217/pgs-20170194

7. Wojtyniak JG, Selzer D, Schwab M, Lehr T. Physiologically based precision dosing approach for drug-drug-gene interactions: a simvastatin network analysis. Clin Pharmacol Ther 2021;109:201-11. doi: 10.1002/cpt.2111

8. Zanger UM, Schwab M. Cytochrome P450 enzymes in drug metabolism: Regulation of gene expression, enzyme activities, and impact of genetic variation. Pharmacol Ther 2013;138:103-41. doi: 10.1016/j.pharmthera.2012.12.007

9. Guengerich FP. Intersection of the roles of cytochrome P450 enzymes with xenobiotic and endogenous substrates: relevance to toxicity and drug interactions. Chem Res Toxicol 2017;30:2-12. doi: 10.1021/acs.chemrestox.6b00226

10. Sim SC, Kacevska M, Ingelman-Sundberg M. Pharmacogenomics of drug-metabolizing enzymes: a recent update on clinical implications and endogenous effects. Pharmacogenomics J 2013;13:1-11. doi: 10.1038/tpj.2012.45

11. Swen JJ, Nijenhuis M, van Rhenen M, de Boer-Veger NJ, Buunk AM, Houwink EJF, Mulder H, Rongen GA, van Schaik RHN, van der Weide J, Wilffert B, Deneer VHM, Guchelaar H-J, on behalf of the DutchPharmacogenetics Working Group (DPWG) of the Royal Dutch Pharmacists Association (KNMP). Pharmacogenetic information in clinical guidelines: The European perspective. Clin Pharmacol Ther 2018;103:795-801. doi: 10.1002/cpt.1049

12. Youssef, E, Kirkdale, CL, Wright, DJ, Guchelaar, H-J, Thornley, T. Estimating the potential impact of implementing 
pre-emptive pharmacogenetic testing in primary care across the UK. Br J Clin Pharmacol 2021;1-19. doi: 10.1111/ bcp. 14704

13. Arjomand-Nahad F, Diefenbach K, Landt O, Gaikovitch E, Roots I. Genotyping of the triallelic variant G2677T/A in MDR1 using LightCycler with locked-nucleic-acid-modified hybridization probes. Anal Biochem 2004;334:201-3. doi: 10.1016/j.ab.2004.07.030

14. Steijns LSW, Van Der Weide J. Ultrarapid drug metabolism: PCR-based detection of CYP2D6 gene duplication. Clin Chem 1998;44:914-7. doi: 10.1093/clinchem/44.5.914

15. Stuven T, Griese EU, Kroemer HK, Eichelbaum M, Zanger UM. Rapid detection of CYP2D6 null alleles by long distance- and multiplex-polymerase chain reaction. Pharmacogenetics 1996;6:417-21. doi: 10.1097/00008571199610000-00005

16. Clinical Pharmacogenetics Implementation Consortium (CPIC) [displayed 15 March 2021]. Available at https:// cpicpgx.org/guidelines/

17. The Royal Dutch Pharmacists Association - Pharmacogenetics Working Group (DPWG). DPWG Pharmacogenomics guidelines [displayed 30 December 2020]. Available at https://www.knmp.nl/downloads/pharmacogeneticrecommendations-november-2020.pdf

18. Agency for Medicinal Products and Medical Devices of Croatia (HALMED). Croatian Annual Report on Drug Utilisation for 2019 [displayed 3015 March 2021]. Available at https:/www.halmed.hr/Novosti-i-edukacije/Publikacijei-izvjesca/Izvjesca-o-potrosnji-lijekova

19. Davies NM, Anderson KE. Clinical pharmacokinetics of diclofenac. Therapeutic insights and pitfalls. Clin Pharmacokinet 1997;33:184-213. doi: 10.2165/00003088199733030-00003

20. Tang W. The metabolism of diclofenac - enzymology and toxicology perspectives. Curr Drug Metab 2003;4:319-29. doi: $10.2174 / 1389200033489398$

21. King C, Tang W, Ngui J, Tephly T, Braun M. Characterization of rat and human UDP-glucuronosyltransferases responsible for the in vitro glucuronidation of diclofenac. Toxicol Sci 2001;61:49-53. doi: 10.1093/toxsci/61.1.49

22. Riess W, Stierlin H, Degen P, Faigle JW, Gerardin A, Moppert J, Sallmann A, Schmid K, Schweizer A, Sulc M, Theobald W, Wagner J. Pharmacokinetics and metabolism of the antiinflammatory agent Voltaren. Scand J Rheumatol 1978;7(Suppl 22):17-29. doi: 10.3109/03009747809097212

23. Lagas JS, Sparidans RW, Wagenaar E, Beijnen JH, Schinkel $\mathrm{AH}$. Hepatic clearance of reactive glucuronide metabolites of diclofenac in the mouse is dependent on multiple ATPbinding cassette efflux transporters. Mol Pharmacol 2010;77:687-94. doi: 10.1124/mol.109.062364

24. Scialis RJ, Aleksunes LM, Csanaky IL, Klaassen CD, Manautou JE. Identification and characterization of efflux transporters that modulate the subtoxic disposition of diclofenac and its metabolites. Drug Metab Dispos 2019;47:1080-92. doi: 10.1124/dmd.119.086603

25. Zhang Y, Han YH, Putluru SP, Matta MK, Kole P, Mandlekar S, Furlong MT, Liu T, Iyer RA, Marathe P, Yang Z, Lai Y, Rodrigues AD. Diclofenac and its acyl glucuronide: determination of in vivo exposure in human subjects and characterization as human drug transporter substrates in vitro.
Drug Metab Dispos 2016;44:320-8. doi: 10.1124/ dmd.115.066944

26. Tomlinson B, Chan P, Zhang Y, Liu Z, Lam CWK. Pharmacokinetics of current and emerging treatments for hypercholesterolemia. Expert Opin Drug Metab Toxicol 2020;16:371-85. doi: 10.1080/17425255.2020.1749261

27. Iwuchukwu OF, Feng Q, Wei WQ, Jiang L, Jiang M, Xu H, Denny JC, Wilke RA, Krauss RM, Roden DM, Stein CM. Genetic variation in the UGT1A locus is associated with simvastatin efficacy in a clinical practice setting. Pharmacogenomics 2014;15:1739-47. doi: 10.2217/ pgs. 14.128

28. Hirota T, Fujita Y, Ieiri I. An updated review of pharmacokinetic drug interactions and pharmacogenetics of statins. Expert Opin Drug Metab Toxicol 2020;16:809-22. doi: 10.1080/17425255.2020.1801634

29. Turner RM, Pirmohamed M. Statin-related myotoxicity: a comprehensive review of pharmacokinetic, pharmacogenomic and muscle components. J Clin Med 2019;9(1):22. doi: 10.3390/jcm9010022

30. Park JE, Kim KB, Bae SK, Moon BS, Liu KH, Shin JG. Contribution of cytochrome P450 3A4 and 3A5 to the metabolism of atorvastatin. Xenobiotica 2008;38:1240-51. doi: 10.1080/00498250802334391

31. Yasar U, Sain-Guven G, Yardimci Y, Kilicarslan A, Babaoglu $\mathrm{MO}$, Bozkurt A. Effect of atorvastatin on CYP2C9 metabolic activity as measured by the formation rate of losartan metabolite in hypercholesterolaemic patients. Basic Clin Pharmacol Toxicol 2011;109:73-7. doi: 10.1111/j.1742-7843.2011.00687.x

32. Vickers S, Duncan CA, Vyas KP, Kari PH, Arison B, Prakash SR, Ramjit HG, Pitzenberger SM, Stokker G, Duggan DE. In vitro and in vivo biotransformation of simvastatin, an inhibitor of HMG CoA reductase. Drug Metab Dispos 1990;18:476-83. PMID: 1976071

33. Lennernäs H. Clinical pharmacokinetics of atorvastatin. Clin Pharmacokinet 2003;42:1141-60. doi: 10.2165/00003088200342130-00005

34. Goosen TC, Bauman JN, Davis JA, Yu C, Hurst SI, Williams JA, Loi C-M. Atorvastatin glucuronidation is minimally and nonselectively inhibited by the fibrates gemfibrozil, fenofibrate, and fenofibric acid. Drug Metab Dispos 2007;35:1315-24. doi: 10.1124/dmd.107.015230

35. Riedmaier S, Klein K, Hofmann U, Keskitalo JE, Neuvonen PJ, Schwab M, Niemi M, Zanger UM. UDPglucuronosyltransferase (UGT) polymorphisms affect atorvastatin lactonization in vitro and in vivo. Clin Pharmacol Ther 2010;87:65-73. doi: 10.1038/clpt.2009.181

36. Prueksaritanont T, Subramanian R, Fang X, Ma B, Qiu Y, Lin JH, Pearson PG, Baillie TA. Glucuronidation of statins in animals and humans: a novel mechanism of statin lactonization. Drug Metab Dispos 2002;30:505-12. doi: 10.1124/dmd.30.5.505

37. Wei WQ, Feng Q, Jiang L, Waitara MS, Iwuchukwu OF, Roden DM, Jiang M, Xu H, Krauss RM; Rotter JI, Nickerson DA, Davis RL, Berg RL, Peissig PL, McCarty CA, Wilke RA, Denny JC. Characterization of statin dose response in electronic medical records. Clin Pharmacol Ther 2014;95:331-8. doi: 10.1038/clpt.2013.202

38. Keskitalo JE, Kurkinen KJ, Neuvoneni PJ, Niemi M. ABCB1 haplotypes differentially affect the pharmacokinetics of the 
acid and lactone forms of simvastatin and atorvastatin. Clin Pharmacol Ther 2008;84:457-61. doi: 10.1038/clpt.2008.25

39. Keskitalo JE, Zolk O, Fromm MF, Kurkinen KJ, Neuvonen PJ, Niemi M. ABCG2 polymorphism markedly affects the pharmacokinetics of atorvastatin and rosuvastatin. Clin Pharmacol Ther 2009;86:197-203. doi: 10.1038/clpt.2009.79

40. Niemi M. Transporter pharmacogenetics and statin toxicity. Clin Pharmacol Ther 2010;87:130-3. doi: 10.1038/ clpt.2009.197

41. Nies AT, Niemi M, Burk O, Winter S, Zanger UM, Stieger $\mathrm{B}$, Schwab M, Schaeffeler E. Genetics is a major determinant of expression of the human hepatic uptake transporter OATP1B1, but not of OATP1B3 and OATP2B1. Genome Med 2013;5(1):1. doi: 10.1186/gm405

42. Moßhammer D, Schaeffeler E, Schwab M, Mörike K. Mechanisms and assessment of statin-related muscular adverse effects. Br J Clin Pharmacol 2014;78:454-66. doi: 10.1111/bcp. 12360

43. Cascorbi I, Haenisch S. Pharmacogenetics of ATP-binding cassette transporters and clinical implications. Methods Mol Biol 2010;596:95-121. doi: 10.1007/978-1-60761-416-6_6

44. Nie Y, Yang J, Liu S, Sun R, Chen H, Long N, Jiang R, Gui C. Genetic polymorphisms of human hepatic OATPs: functional consequences and effect on drug pharmacokinetics. Xenobiotica 2020;50:297-317. doi: 10.1080/00498254.2019.1629043

45. Menassé R, Hedwall PR, Kraetz J, Pericin C, Riesterer L, Sallmann A, Ziel R, Jaques R. Pharmacological properties of diclofenac sodium and its metabolites. Scand J Rheumatol 1978;7(Suppl 22):5-16. doi: 10.3109/03009747809097211

46. Kim G-H. Renal effects of prostaglandins and cyclooxygenase-2 inhibitors. Electrolyte Blood Press 2008;6:35-41. doi: 10.5049/EBP.2008.6.1.35

47. Whelton A. Nephrotoxicity of nonsteroidal anti-inflammatory drugs: physiologic foundations and clinical implications. Am J Med 1999;106(5B):13S-24S. doi: 10.1016/s00029343(99)00113-8

48. John CM, Shukla R, Jones CA. Using NSAID in volume depleted children can precipitate acute renal failure. Arch Dis Child 2007;92:524-6. doi: 10.1136/adc.2006.103564

49. Zi J, Liu D, Ma P, Huang H, Zhu J, Wei D, Yang J, Chen C. Effects of CYP2C9*3 and CYP2C9*13 on diclofenac metabolism and inhibition-based drug-drug interactions. Drug Metab Pharmacokinet 2010;25:343-50. doi: 10.2133/ dmpk.dmpk-10-rg-009

50. Maekawa K, Harakawa N, Sugiyama E, Tohkin M, Kim SR, Kaniwa N, Katori N, Hasegawa R, Yasuda K, Kamide K, Miyata T, Saito Y, Sawada J. Substrate-dependent functional alterations of seven CYP2C9 variants found in Japanese subjects. Drug Metab Dispos 2009;37:1895-903. doi: 10.1124/dmd.109.027003

51. Xia M-M, Wang L, PAan P-P, Wang H-Y, Chen M-C, Chen Y, Dai D-P, Cai J-P, Hu G-X. The role of CYP2C9 genetic polymorphisms in the oxidative metabolism of diclofenac in vitro. Pharmazie 2014;69:898-903. PMID: 25951663

52. Dorado P, Cavaco I, Cáceres MC, Piedade R, Ribeiro V, Llerena A. Relationship between CYP2C8 genotypes and diclofenac 5-hydroxylation in healthy Spanish volunteers. Eur J Clin Pharmacol 2008;64:967-70. doi: 10.1007/s00228008-0508-4
53. Kirchheiner J, Meineke I, Steinbach N, Meisel C, Roots I, Brockmöller J. Pharmacokinetics of diclofenac and inhibition of cyclooxygenases 1 and 2: no relationship to the CYP2C9 genetic polymorphism in humans. Br J Clin Pharmacol 2003;55:51-61. doi: 10.1046/j.1365-2125.2003.01712.x

54. Theken KN, Lee CR, Gong L, Caudle KE, Formea CM, Gaedigk A, Klein TE, Agúndez JAG, Grosser T. Clinical Pharmacogenetics Implementation Consortium Guideline (CPIC) for CYP2C9 and nonsteroidal anti-inflammatory drugs. Clin Pharmacol Ther 2020;108:191-200. doi: 10.1002/ cpt. 1830

55. Shahabi P, Siest G, Meyer UA, Visvikis-Siest S. Human cytochrome P450 epoxygenases: variability in expression and role in inflammation-related disorders. Pharmacol Ther 2014;144:134-61. doi: 10.1016/j.pharmthera.2014.05.011

56. Capdevila JH, Wang W, Falck JR. Arachidonic acid monooxygenase: Genetic and biochemical approaches to physiological/pathophysiological relevance. Prostaglandins Other Lipid Mediat 2015;120:40-9. doi: 10.1016/j. prostaglandins.2015.05.004

57. Fan F, Roman RJ. Effect of cytochrome P450 metabolites of arachidonic acid in nephrology. J Am Soc Nephrol 2017;28:2845-55. doi: 10.1681/ASN.2017030252

58. Fan F, Ge Y, Lv W, Elliott MR, Muroya Y, Hirata T, Booz GW, Roman RJ. Molecular mechanisms and cell signaling of 20-hydroxyeicosatetraenoic acid in vascular pathophysiology. Front Biosci (Landmark Ed) 2016;21:142763. PMCID: PMC5064940

59. Dey A, Maric C, Kaesemeyer WH, Zaharis CZ, Stewart J, Pollock JS, Imig JD. Rofecoxib decreases renal injury in obese Zucker rats. Clin Sci (Lond) 2004;107:561-70. doi: 10.1042/CS20040125

60. Sausville LN, Gangadhariah MH, Chiusa M, Mei S, Wei S, Zent R, Luther JM, Shuey MM, Capdevila JH, Falck JR, Guengerich FP, Williams SM, Pozzi A. The cytochrome P450 slow metabolizers CYP2C9*2 and CYP2C9*3 directly regulate tumorigenesis via reduced epoxyeicosatrienoic acid production. Cancer Res 2018;78:4865-77. doi: 10.1158/00085472.CAN-17-3977

61. Imig JD. Epoxyeicosatrienoic acids, hypertension, and kidney injury. Hypertension 2015;65:476-82. doi: 10.1161/ HYPERTENSIONAHA.114.03585

62. Imig JD, Khan MAH. Cytochrome P450 and lipoxygenase metabolites on renal function. Compr Physiol 2015;6:423-41. doi: 10.1002/cphy.c150009

63. Das A, Weigle AT, Arnold WR, Kim JS, Carnevale LN, Huff HC. CYP2J2 molecular recognition: a new axis for therapeutic design. Pharmacol Ther 2020;215:107601. doi: 10.1016/j.pharmthera.2020.107601

64. Wang SY, Xing PF, Zhang CY, Deng BQ. Association of CYP2J2 gene polymorphisms with ischemic stroke and stroke subtypes in Chinese population. Medicine (Baltimore) 2017;96(10):e6266. doi: 10.1097/MD.0000000000006266

65. Jarrar YB, Cha E-Y, Seo K-A, Ghim J-L, Kim H-J, Kim D-H, Lee S-J, Shin J-G. Determination of major UDPglucuronosyltransferase enzymes and their genotypes responsible for 20-HETE glucuronidation. J Lipid Res 2014;55:2334-42. doi: 10.1194/jlr.M051169

66. Ward NC, Puddey IB, Hodgson JM, Beilin LJ, Croft KD. Urinary 20-hydroxyeicosatetraenoic acid excretion is associated with oxidative stress in hypertensive subjects. Free 
Radic Biol Med 2005;38:1032-6. doi: 10.1016/j. freeradbiomed.2004.12.024

67. Holthe M, Rakvåg TN, Klepstad P, Idle JR, Kaasa S, Krokan HE, Skorpen F. Sequence variations in the UDPglucuronosyltransferase 2B7 (UGT2B7) gene: identification of 10 novel single nucleotide polymorphisms (SNPs) and analysis of their relevance to morphine glucuronidation in cancer patients. Pharmacogenomics J 2003;3:17-26. doi: 10.1038/sj.tpj.6500139

68. Daly AK, Aithal GP, Leathart JBS, Swainsbury RA, Dang TS, Day CP. Genetic susceptibility to diclofenac-induced hepatotoxicity: contribution of UGT2B7, CYP2C8, and ABCC2 genotypes. Gastroenterology 2007;132:272-81. doi: 10.1053/j.gastro.2006.11.023

69. Jarrar YB, Kim DH, Lee SJ, Shin JG. Inhibition of 20-hydroxyeicosatetraenoic acid (20-HETE) glucuronidation by non-steroidal anti-inflammatory drugs in human liver microsomes and recombinant UDP-glucuronosyltransferase enzymes. Prostaglandins Leukot Essent Fatty Acids 2020;153:102055. doi: 10.1016/j.plefa.2020.102055

70. Lazarska KE, Dekker SJ, Vermeulen NPE, Commandeur JNM. Effect of UGT2B7 $* 2$ and CYP2C $8 * 4$ polymorphisms on diclofenac metabolism. Toxicol Lett 2018;284:70-8. doi: 10.1016/j.toxlet.2017.11.038

71. Coffman BL, King CD, Rios GR, Tephly TR. The glucuronidation of opioids, other xenobiotics, and androgens by human UGT2B7Y(268) and UGT2B7H(268). Drug Metab Dispos 1998;26:73-7. PMID: 9443856

72. Bélanger AS, Caron P, Harvey M, Zimmerman PA, Mehlotra RK, Guillemette C. Glucuronidation of the antiretroviral drug efavirenz by UGT2B7 and an in vitro investigation of drugdrug interaction with zidovudine. Drug Metab Dispos 2009;37:1793-6. doi: 10.1124/dmd.109.027706

73. Barbier O, Turgeon D, Girard C, Green MD, Tephly TR, Hum DW. 3'-azido-3'-deoxythimidine (AZT) is glucuronidated by human UDP-glucuronosyltransferase 2B7 (UGT2B7). Drug Metab Dispos 2000;28:497-502. PMID: 10772627

74. Wang H, Yuan L, Zeng S. Characterizing the effect of UDPglucuronosyltransferase (UGT) 2B7 and UGT1A9 genetic polymorphisms on enantioselective glucuronidation of flurbiprofen. Biochem Pharmacol 2011;82:1757-63. doi: 10.1016/j.bcp.2011.08.004

75. Duguay Y, Báár C, Skorpen F, Guillemette C. A novel functional polymorphism in the uridine diphosphateglucuronosyltransferase $2 \mathrm{~B} 7$ promoter with significant impact on promoter activity. Clin Pharmacol Ther 2004;75:223-33. doi: 10.1016/j.clpt.2003.10.006

76. Thibaudeau J, Lépine J, Tojcic J, Duguay Y, Pelletier G, Plante M, Brisson J, Têtu B, Jacob S, Perusse L, Bélanger A, Guillemette C. Characterization of common UGT1A8, UGT1A9, and UGT2B7 variants with different capacities to inactivate mutagenic 4-hydroxylated metabolites of estradiol and estrone. Cancer Res 2006;66:125-33. doi: 10.1158/00085472.CAN-05-2857

77. Urban TJ, Shen Y, Stolz A, Chalasani N, Fontana RJ, Rochon J, Ge D, Shianna KV, Daly AK, Lucena MI, Nelson MR, Molokhia M, Aithal GP, Floratos A, Pe'er I, Serrano J, Bonkovsky H, Davern TJ, Lee WM, Navarro VJ, Talwalkar JA, Goldstein DB, Watkins PB, on behalf of the DrugInduced Liver Injury Network, DILIGEN, EUDRAGENE, the Spanish DILI Registry, and the International Serious Adverse Events Consortium. Limited contribution of common genetic variants to risk for liver injury due to a variety of drugs. Pharmacogenet Genomics 2012;22:784-95. doi: 10.1097/FPC.0b013e3283589a76

78. Lagas JS, van der Kruijssen CM, van de Wetering K, Beijnen JH, Schinkel AH. Transport of diclofenac by breast cancer resistance protein $(\mathrm{ABCG} 2)$ and stimulation of multidrug resistance protein 2 (ABCC2)-mediated drug transport by diclofenac and benzbromarone. Drug Metab Dispos 2009;37:129-36. doi: 10.1124/dmd.108.02320.

79. Daly AK. Are polymorphisms in genes relevant to drug disposition predictors of susceptibility to drug-induced liver injury? Pharm Res 2017;34:1564-9. doi: 10.1007/s11095016-2091-1

80. Haenisch S, Zimmermann U, Dazert E, Wruck CJ, Dazert P, Siegmund W, Kroemer HK, Warzok RW, Cascorbi I. Influence of polymorphisms of $\mathrm{ABCB} 1$ and $\mathrm{ABCC} 2$ on mRNA and protein expression in normal and cancerous kidney cortex. Pharmacogenomics J 2007;7:56-65. doi: 10.1038/sj.tpj.6500403

81. Saku K, Zhang B, Noda K. Randomized head-to-head comparison of pitavastatin, atorvastatin, and rosuvastatin for safety and efficacy (quantity and quality of LDL): the PATROL trial. Circ J 2011;75:1493-505. doi: 10.1253/circj. cj-10-1281

82. Ooba N, Sato T, Wakana A, Orii T, Kitamura M, Kokan A, Kurata H, Shimodozono Y, Matsui K, Yoshida H, Yamaguchi T, Kageyama S, Kubota K. A prospective stratified casecohort study on statins and multiple adverse events in Japan. PLoS One 2014;9(5):e96919. doi: 10.1371/journal. pone.0096919

83. Staud F, Ceckova M, Micuda S, Pavek P. Expression and function of p-glycoprotein in normal tissues: effect on pharmacokinetics. Methods Mol Biol 2010;596:199-222. doi: 10.1007/978-1-60761-416-6_10

84. Duman I. Role of pharmacogenetics on response to statins: a genotype-based approach to statin therapy outcome. J Cardiol Ther 2014;1:111-20. doi: 10.6051/j.issn.23096861.2014.01.35

85. Zubiaur P, Benedicto MD, Villapalos-García G, NavaresGómez M, Mejía-Abril G, Román M, Martín-Vílchez S, Ochoa D, Abad-Santos F. SLCO1B1 phenotype and CYP3A5 polymorphism significantly affect atorvastatin bioavailability. J Pers Med 2021;11:1-15. doi: 10.3390/jpm11030204

86. Fukunaga K, Nakagawa H, Ishikawa T, Kubo M, Mushiroda T. ABCB1 polymorphism is associated with atorvastatininduced liver injury in Japanese population. BMC Genet 2016;17:79. doi: 10.1186/s12863-016-0390-5

87. Gandelman K, Fung GL, Messig M, Laskey R. Systemic exposure to atorvastatin between Asian and Caucasian subjects: a combined analysis of 22 studies. Am J Ther 2012;19:164-73. doi: 10.1097/MJT.0b013e3181f28fb5

88. Karaca RO, Kalkisim S, Altinbas A, Kilincalp S, Yuksel I, Goktas MT, Yasar U, Bozkurt A, Babaoglu MO. Effects of genetic polymorphisms of cytochrome P450 enzymes and MDR1 transporter on pantoprazole metabolism and Helicobacter pylori eradication. Basic Clin Pharmacol Toxicol 2017;120:199-206. doi: 10.1111/bcpt.12667

89. Safar Z, Kis E, Erdo F, Zolnerciks JK, Krajcsi P. ABCG2/ BCRP: variants, transporter interaction profile of substrates 
and inhibitors. Expert Opin Drug Metab Toxicol 2019;15:31328. doi: 10.1080/17425255.2019.1591373

90. Hu M, To KKW, Mak VWL, Tomlinson B. The ABCG2 transporter and its relations with the pharmacokinetics, drug interaction and lipid-lowering effects of statins. Expert Opin Drug Metab Toxicol 2011;7:49-62. doi: $10.1517 / 17425255.2011 .538383$

91. Tsamandouras N, Guo Y, Wendling T, Hall S, Galetin A, Aarons L. Modelling of atorvastatin pharmacokinetics and the identification of the effect of a BCRP polymorphism in the Japanese population. Pharmacogenet Genomics 2017;27:27-38. doi: 10.1097/FPC.0000000000000252

92. Mirosevic Skvrce N, Macolic Sarinic V, Simic I, Ganoci L, Muacevic Katanec D, Bozina N. ABCG2 gene polymorphisms as risk factors for atorvastatin adverse reactions: a casecontrol study. Pharmacogenomics 2015;16:803-15. doi: $10.2217 /$ pgs. 15.47

93. US Food and Drug Administration. Clinical Drug Interaction Studies - Study Design, Data Analysis, and Clinical Implications. Guidance for Industry [displayed 30 April 2021]. Available at https://www.fda.gov/drugs/druginteractions-labeling/drug-interactions-relevant-regulatoryguidance-and-policy-documents

94. European Medicines Agency. Guideline on the investigation of drug interactions CPMP/EWP/560/95/rev. 1 Corr. 2**. Committee for Human Medicinal Products (CHMP) [displayed 30 April 2021]. Available at http://www.ema. europa.eu/docs/en_GB/document_library/Scientific guideline/2012/07/\%0AWC500129606.pdf

95. Endres CJ, Hsiao P, Chung FS, Unadkat JD. The role of transporters in drug interactions. Eur J Pharm Sci 2006;27:501-17. doi: 10.1016/j.ejps.2005.11.002

96. Hermann M, Bogsrud MP, Molden E, Asberg A, Mohebi BU, Ose L, Retterstøl K. Exposure of atorvastatin is unchanged but lactone and acid metabolites are increased several-fold in patients with atorvastatin-induced myopathy. Clin Pharmacol Ther 2006;79:532-9. doi: 10.1016/j. clpt.2006.02.014

97. Stormo C, Bogsrud MP, Hermann M, Åsberg A, Piehler AP, Retterstøl K, Kringen MK. UGT1A1*28 is associated with decreased systemic exposure of atorvastatin lactone. Mol Diagn Ther 2013;17:233-7. doi: 10.1007/s40291-013-0031-x

98. Sakaeda T, Kadoyama K, Okuno Y. Statin-associated muscular and renal adverse events: data mining of the public version of the FDA adverse event reporting system. PLoS One 2011;6(12):e28124. doi: 10.1371/journal.pone.0028124

99. Chang C-H, Kusama M, Ono S, Sugiyama Y, Orii T, Akazawa M. Assessment of statin-associated muscle toxicity in Japan: a cohort study conducted using claims database and laboratory information. BMJ Open 2013;3(4):e002040. doi: 10.1136/bmjopen-2012-002040

100. Elsby R, Hilgendorf C, Fenner K. Understanding the critical disposition pathways of statins to assess drug-drug interaction risk during drug development: it's not just about OATP1B1. Clin Pharmacol Ther 2012;92:584-98. doi: 10.1038/ clpt.2012.163

101. National Center for Biotechnology Information. Reference SNP (rs) Report [displayed 30 April 2021]. Available at https://www.ncbi.nlm.nih.gov/snp/rs4149056\#frequency_tab

102. Tarantino N, Santoro F, De Gennaro L, Correale M, Guastafierro F, Gaglione A, Di Biase M, Brunetti ND.
Fenofibrate/simvastatin fixed-dose combination in the treatment of mixed dyslipidemia: safety, efficacy, and place in therapy. Vasc Health Risk Manag 2017;13:29-41. doi: 10.2147/VHRM.S95044

103. Prueksaritanont T, Richards KM, Qiu Y, Strong-Basalyga K, Miller A, Li C, Eisenhandler R, Carlini EJ. Comparative effects of fibrates on drug metabolizing enzymes in human hepatocytes. Pharm Res 2005;22:71-8. doi: 10.1007/s11095004-9011-5

104. Davidson MH. Statin/fibrate combination in patients with metabolic syndrome or diabetes: evaluating the risks of pharmacokinetic drug interactions. Expert Opin Drug Saf 2006;5:145-56. doi: 10.1517/14740338.5.1.145

105. Yamazaki M, Li B, Louie SW, Pudvah NT, Stocco R, Wong W, Abramovitz M, Demartis A, Laufer R, Hochman JH, Prueksaritanont T, Lin JH. Effects of fibrates on human organic anion-transporting polypeptide 1B1-, multidrug resistance protein 2- and P-glycoprotein-mediated transport. Xenobiotica 2005;35:737-53. doi: $10.1080 / 00498250500136676$

106. Poruba M, Matuskova Z, Hüttl M, Malinska H, Oliyarnyk O, Markova I, Gurska S, Kazdova L, Vecera R. Fenofibrate decreases hepatic P-glycoprotein in a rat model of hereditary hypertriglyceridemia. Front Pharmacol 2019;10:56. doi: 10.3389/fphar.2019.00056

107. Wen X, Wang J-S, Backman JT, Laitila J, Neuvonen PJ. Trimethoprim and sulfamethoxazole are selective inhibitors of CYP2C8 and CYP2C9, respectively. Drug Metab Dispos 2002;30:631-5. doi: 10.1124/dmd.30.6.631

108. Turner RM, Fontana V, FitzGerald R, Morris AP, Pirmohamed $M$. Investigating the clinical factors and comedications associated with circulating levels of atorvastatin and its major metabolites in secondary prevention. Br J Clin Pharmacol 2020;86:62-74. doi: 10.1111/bcp.14133

109. Li XQ, Andersson TB, Ahlström M, Weidolf L. Comparison of inhibitory effects of the proton pump-inhibiting drugs omeprazole, esomeprazole, lansoprazole, pantoprazole, and rabeprazole on human cytochrome P450 activities. Drug Metab Dispos 2004;32:821-7. doi: 10.1124/dmd.32.8.821

110. Pauli-Magnus C, Rekersbrink S, Klotz U, Fromm MF. Interaction of omeprazole, lansoprazole and pantoprazole with P-glycoprotein. Naunyn Schmiedebergs Arch Pharmacol 2001;364:551-7. doi: 10.1007/s00210-001-0489-715

111. Luciani F, Spada M, De Milito A, Molinari A, Rivoltini L, Montinaro A, Marra M, Lugini L, Logozzi M, Lozupone F, Federici C, Iessi E, Parmiani G, Arancia G, Belardelli F, Fais $\mathrm{S}$. Effect of proton pump inhibitor pretreatment on resistance of solid tumors to cytotoxic drugs. J Natl Cancer Inst 2004;96:1702-13. doi: 10.1093/jnci/djh305

112. Balayssac D, Authier N, Cayre A, Coudore F. Does inhibition of P-glycoprotein lead to drug-drug interactions? Toxicol Lett 2005;156:319-29. doi: 10.1016/j.toxlet.2004.12.008

113. Nakaharai K, Sakamoto Y, Yaita K, Yoshimura Y, Igarashi S, Tachikawa N. Drug-induced liver injury associated with high-dose ceftriaxone: a retrospective cohort study adjusted for the propensity score. Eur J Clin Pharmacol 2016;72:100311. doi: 10.1007/s00228-016-2064-7

114. Ebner T, Ishiguro N, Taub ME. The use of transporter probe drug cocktails for the assessment of transporter-based drugdrug interactions in a clinical setting-proposal of a four 
component transporter cocktail. J Pharm Sci 2015;104:3220 8. doi: 10.1002/jps.24489

115. Hasegawa M, Kusuhara H, Adachi M, Schuetz JD, Takeuchi $\mathrm{K}$, Sugiyama Y. Multidrug resistance-associated protein 4 is involved in the urinary excretion of hydrochlorothiazide and furosemide. J Am Soc Nephrol 2007;18:37-45. doi: 10.1681/ ASN.2005090966
116. Klarica Domjanović I, Lovrić M, Trkulja V, Petelin-Gadže Ž, Ganoci L, Čajić I, Božina N. Interaction between ABCG2 $421 \mathrm{C}>\mathrm{A}$ polymorphism and valproate in their effects on steady-state disposition of lamotrigine in adults with epilepsy. Br J Clin Pharmacol 2018;84:2106-19. doi: 10.1111/ bcp. 13646

\section{Interakcije lijek-lijek-gen kao posrednici nuspojava diklofenaka i statina - prikaz slučaja i pregled literature}

Statini i nesteroidni protuupalni lijekovi (NSAID) učestalo se propisuju, pa i kao konkomitantna terapija. Postoji značajna interindividualna razlika u osjetljivosti na njihove najčešće nuspojave. Rizični čimbenici za razvoj nuspojava tih lijekova mogu biti povezani s lijekom i pacijentom ili s vanjskim čimbenicima. Polifarmacija je česta u kroničnih bolesnika i povećava rizik od razvoja interakcija lijekova. Istodobna primjena lijekovima koji inhibiraju CYP, UGT, ABC i / ili SLC prijenosnike lijekova (ABCB1, ABCG2 i OATP1B1) povezana je s produljenjem bioraspoloživosti lijekova, što rezultira povećanim rizikom od razvoja nuspojava. S tim u vezi, predstavljamo slučaj 46-godišnje žene koja je tijekom dvije godine doživjela akutno oštećenje bubrega i jetre, kao i mialgiju, dok je uzimala diklofenak, atorvastatin, fiksnu kombinaciju simvastatina / fenofibrata istovremeno s nekoliko drugih lijekova, uključujući pantoprazol i furosemid. Analiza dobivenih farmakogenetičkih rezultata te pregled dosadašnjeg znanja u tom području upućuju na zaključke da interakcije lijek-lijekgen mogu produljiti bioraspoloživost primijenjenih lijekova. Mehanizam se argumentirano temelji na sporijoj sposobnosti detoksikacije i smanjenoj eliminaciji putem jetre i bubrega, što rezultira toksičnošću za više organa. Jednako tako, prikazuje se važnost polimorfizama CYP u biotransformaciji endogenih supstrata poput arahidonske kiseline i u njihovoj modulacijskoj ulozi u patofiziološkim procesima. Danas postoje prilično značajni znanstveni dokazi o određenim farmakogenetičkim spoznajama koji rezultiraju povećanim rizikom od razvoja nuspojava za spomenute lijekove, no unatoč tomu, farmakogenetička analiza prije uvođenja lijekova u terapiju još nije uvedena u redovitu kliničku praksu.

KLJUČNE RIJEČI: farmakogenetika; hepatotoksičnost; interakcije lijekova; miotoksičnost; nefrotoksičnost 